\title{
The lichen genus Usnea (Pameliaceae) in tropical South America: species with a pigmented medulla, reacting $\mathrm{C}+$ yellow
}

\author{
Camille TRUONG and Philippe CLERC
}

\begin{abstract}
In tropical South America (Venezuela, Colombia, Ecuador, Peru, Bolivia and Brazil), we investigated the diversity of Usnea species with a pigmented, $\mathrm{C}+$ yellow medulla. Four species are treated: the sorediate $U$. ceratina and $U$. entoviolata, the latter being new for South America, and the non-sorediate $U$. cristatula and $U$. flavorubescens, the latter being newly described here. A detailed description is provided for each species together with an identification key.
\end{abstract}

Key words: chemistry, endemism, morphology, Neotropics, taxonomy

Accepted for publication 21 April 2012

\section{Introduction}

Usnea Adans. is a large genus in the family Parmeliaceae, with more than 350 species (Clerc 1998) that are widely distributed in polar, temperate and tropical regions. The genus is recognized based on the fruticose thallus, branches with a cartilaginous central axis and the presence of usnic acid in the cortex. At the species level, the extensive plasticity of morphological characters, in response to environmental parameters, greatly challenges the delimitation of species (Clerc 1998) and numerous taxa have been reduced to synonymy. Since Motyka's world monograph (1936-38), modern revisions of the genus Usnea have been completed in Europe (Clerc 1987b, 1992, 2011b; Halonen et al. 1999), Macaronesia (Clerc 2006), North America (Clerc \& Herrera-Campos 1997; Halonen et al. 1998; Herrera-Campos et al. 1998, 2001; Clerc 2008), Eastern Asia (Ohmura 2001; Ohmura et al. 2010), East Africa (Swinscow \& Krog 1978, 1979), Australia (Stevens 1999, 2004), India (Awasthi

C. Truong and P. Clerc: Conservatoire et Jardin botaniques de la Ville de Genève, CP 60, 1292 Chambésy, Switzerland; Laboratoire de systématique végétale et biodiversité, Faculté des sciences de l'Université de Genève, CP 60, 1292 Chambésy, Switzerland.

Email: camille.truong@ville-ge.ch
1986) and polar regions (Seymour et al. 2007; Wirtz et al. 2008). South America exhibits a high diversity of Usnea species that is still poorly known (Truong et al. 2011). An ongoing investigation of the taxonomic diversity of Usnea was started recently in South America and the Galapagos (Rodriguez et al. 2011; Truong et al. 2011).

Medullary pigmentation has a strong taxonomic value to delimit several Usnea species (Swinscow \& Krog 1979; Ohmura 2001; Truong et al. 2011). Two types of pigmentation are recognized in the medulla of Usnea species (Ohmura 2001): 1) a reddish orange, subcortical pigmentation; 2) a pinkish pigmentation, reacting $\mathrm{C}+$ yellow and $\mathrm{CK}+$ orange. The exact nature of these pigments is still unclear. Ohmura (2001) suggested, based on East Asian material, that the subcortical orange pigmentation of $U$. dorogawensis was secreted inside the cell walls of the hyphae, whereas the pinkish pigmentation of $U$. baileyi, $U$. ceratina and $U$. mutabilis resulted from the accumulation of bisxanthones (such as eumitrins) outside the cell walls of the hyphae. However, in several species with a pinkish pigmentation (including $U$. ceratina) the presence of bisxanthones has not yet been confirmed. The correlation of these pigments with the presence of specific metabolites detected by TLC (for example 
TABLE 1. Distribution per country* and altitudinal range of Usnea species

\begin{tabular}{|l|r|c|c|c|c|c|c|c|}
\hline Species & $n \dagger$ & BOL & BRA & COL & ECU & PER & VEN & Altitude (m) \\
\hline U. ceratina & 145 & + & + & + & + & + & + & $600-3500$ \\
\hline U. cristatula & 28 & + & & + & & + & + & $450-3000$ \\
\hline U. entoviolata & 61 & + & + & + & & + & + & $1000-3000$ \\
\hline U. flavorubescens & 5 & & & & & + & & $2000-2700$ \\
\hline
\end{tabular}

* BOL, Bolivia; BRA, Brazil; COL, Colombia; ECU, Ecuador (excluding the Galapagos); PER, Peru; VEN, Venezuela.

$\dagger n=$ number of specimens studied.

diffractaic acid) is also not clear. To truly characterize these pigments, a detailed study using microscopy coupled with quantifying chemical analysis such as high-performance liquid chromatography would be needed. The use of spot tests (for example the C+ reaction), although not permitting identification to a specific metabolite or pigment, remains useful to identify the species based on their medullary reactions.

Species with a reddish orange, subcortical pigmentation (e.g. U. dorogawensis Asahina, $U$. steineri Zahlbr., U. subdasaea Truong \& Clerc) have recently been treated in South America (Truong et al. 2011). Species with a pinkish pigmentation are either 'eumitrioid', characterized by a tubular central axis throughout the whole thallus, or have a solid central axis. Eumitrioid species [e.g. $U$. baileyi (Stirt.) Zahlbr., U. perplectata Motyka] in South America will be studied separately in a forthcoming publication. This study treats the species with a solid central axis and a pinkish medulla, reacting $\mathrm{C}+$ yellow, occurring in tropical South America. This group of species corresponds to $U$. ceratina Ach. and related species.

\section{Materials and Methods}

This study is based mainly on material collected by the first author in Bolivia, Ecuador and Peru, as well as herbarium specimens collected in Colombia by $\mathrm{H}$. Sipman (B) and in Venezuela by M. E. Hale, Jr. (US). For a detailed description of the collection sites see Truong et al. (2011). In addition, material from Brazil came mainly from the collections of SP and K. Kalb (private hb.). Specimens and types from the following herbaria were included: B, G, H, LBL and W. Table 1 indicates the number of specimens studied, their distribution per country and their altitudinal range. Since none of the species from this group occur in the Galapagos, this region was not included here. Only synonyms that have been published for South America are mentioned.

Morphology of specimens was examined using a Leica MS5 stereomicroscope. The medullar pigmentation was studied in longitudinal sections of branches: colours of pigments were defined using a colour identification chart (Isley 1987), which is available online at http:// fcbs.org/articles/color_chart.htm. The exact nature of these pigments remains unknown and the use of spot tests does not permit identification to a specific metabolite or a pigment, but spot tests remain good discriminators to identify this group of species (medulla $\mathrm{C}+$ ). Thickness of the cortex/medulla/axis was measured in longitudinal sections of branches at $\times 40$ magnification (the largest part of the largest branch, but not the trunk) and the percentage of the total branch diameter (CMA) was calculated according to Clerc (1987b), as well as the ratio of the thickness of axis/medulla $(\mathrm{A} / \mathrm{M})$. In the description of species, CMA values are given with their standard deviations and follow the categories described by Clerc $(2011 b)$ : the cortex is thin $(<6 \%)$, moderately thin $(6-8 \%)$, moderately thick $(8-10 \%)$ or thick $(>10 \%)$; the medulla is thin $(<18 \%)$, moderately thin $(18-23 \%)$, moderately thick $(23-28 \%)$ or thick $(>28 \%)$; the axis is thin $(<30 \%)$, moderately thin $(30-40 \%)$, moderately thick $(40-50 \%)$ or thick $(>50 \%)$. Spores were observed with a Leica DM 2000 microscope and at least 10 spores per specimen were measured at $\times 1000$ magnification.

Chemical analyses were performed by thin-layer chromatography (TLC) following the method of Culberson \& Ammann (1979), with solvent B modified according to Culberson \& Johnson (1982).

\section{Diagnostic characters}

Usnea species may exhibit a high morphological variation according to varying environmental parameters and the choice of stable diagnostic characters is crucial for the delim- 
TABLE 2. Major secondary metabolites (columns) and chemotypes (lines) detected by TLC in the medulla of the Usnea species

\begin{tabular}{|l|r|r|c|c|c|}
\hline \multicolumn{2}{|l|}{ Species/chemotype } & $n$ & BAR & DIF & NOR \\
\hline U. ceratina & \multicolumn{1}{c|}{$/ 1$} & 81 & \pm & + & - \\
\hline & $/ 2$ & 3 & + & - & - \\
\hline U. cristatula & $/ 1$ & 27 & \pm & + & - \\
\hline & $/ 2$ & 1 & + & - & - \\
\hline U. entoviolata & \multicolumn{1}{|c|}{$/ 1$} & 30 & \pm & + & - \\
\hline & $/ 2$ & 1 & + & - & - \\
\hline U. flavorubescens & 5 & \pm & - & + \\
\hline
\end{tabular}

$n=$ number of specimens studied; + , presence in all specimens studied; \pm , presence variable among specimens; -, absent; BAR, barbartic; DIF, diffractaic; NOR, norstictic acids.

itation of species. The following characters were used to delimit species within this group:

Tubercles or fibercles. Tubercles are protuberances on the cortex surface, that are filled with medulla and sometimes erode at the top (Swinscow \& Krog 1979). Fibercles occur from the breaking of fibrils, resulting in a stipitate scar, with the central axis sometimes visible (Clerc \& Herrera-Campos 1997). Both structures may look similar at first glance, but their ontogeny is clearly different. The potential of species to produce either of these structures is of great taxonomic importance (Clerc 1998): here $U$. ceratina, $U$. cristatula and $U$. entoviolata mostly produce tubercles whereas $U$. flavorubescens mostly produces fibercles.

Soralia. Soralia are an essential character in the taxonomy of Usnea (Clerc 1998), not only their presence but also their morphology (Clerc 1987a) and their ontogeny (Clerc \& Herrera-Campos 1997; Ohmura 2001). The two sorediate species in this group, U. ceratina and $U$. entoviolata, are distinguished by both the origin and the shape of soralia.

Chemistry. The chemistry in this group is not very diverse with only three major metabolites detected by TLC in the medulla (Table 2). Usnea flavorubescens is distinguished by the presence of norstictic acid; all other species have diffractaic and/or barbatic acid in the medulla.
All species exhibit similar CMA values (Fig. 1). Spore size was also similar among the species. The shape of branches and segments or the constriction of branches at the attachment point are useful characters to delimit numerous Usnea species (Clerc 1998, $2011 b$ ). These characters show an unusually high variability in $U$. ceratina and $U$. cristatula and are therefore difficult to interpret in this group of species.

\section{The Species}

\section{Usnea ceratina Ach.}

Lich. Univ.: 619 (1810); type: [Poland], Silesia, Mosig (H-ACH 1890!-lectotype). \% C/M/A: 9.5/23/35. Chemistry: usnic, diffractaic, barbatic and squamatic acids (Herrera-Campos et al. 1998).

Usnea solida Motyka, Lich. Gen. Usnea Stud. Monogr. Pars Syst. 2: 382 (1938); type: Mexico, Veracruz, Jalapa, 1840, Galeotti (W!-holotype). \% C/M/A: 12.5/21/33. Chemistry: usnic, diffractaic, barbatic acids and various unknown accompanying substances (Herrera-Campos et al. 1998).

\section{(Figs 2A-C, 3A-D \& G)}

For a detailed description of this taxon, see Herrera-Campos et al. (1998) and Ohmura (2001).

Diagnostic notes. Usnea ceratina is characterized by a stiff thallus, with a very hard and vitreous cortex (in longitudinal section) that is moderately thick to thick (Fig. 1), and a 

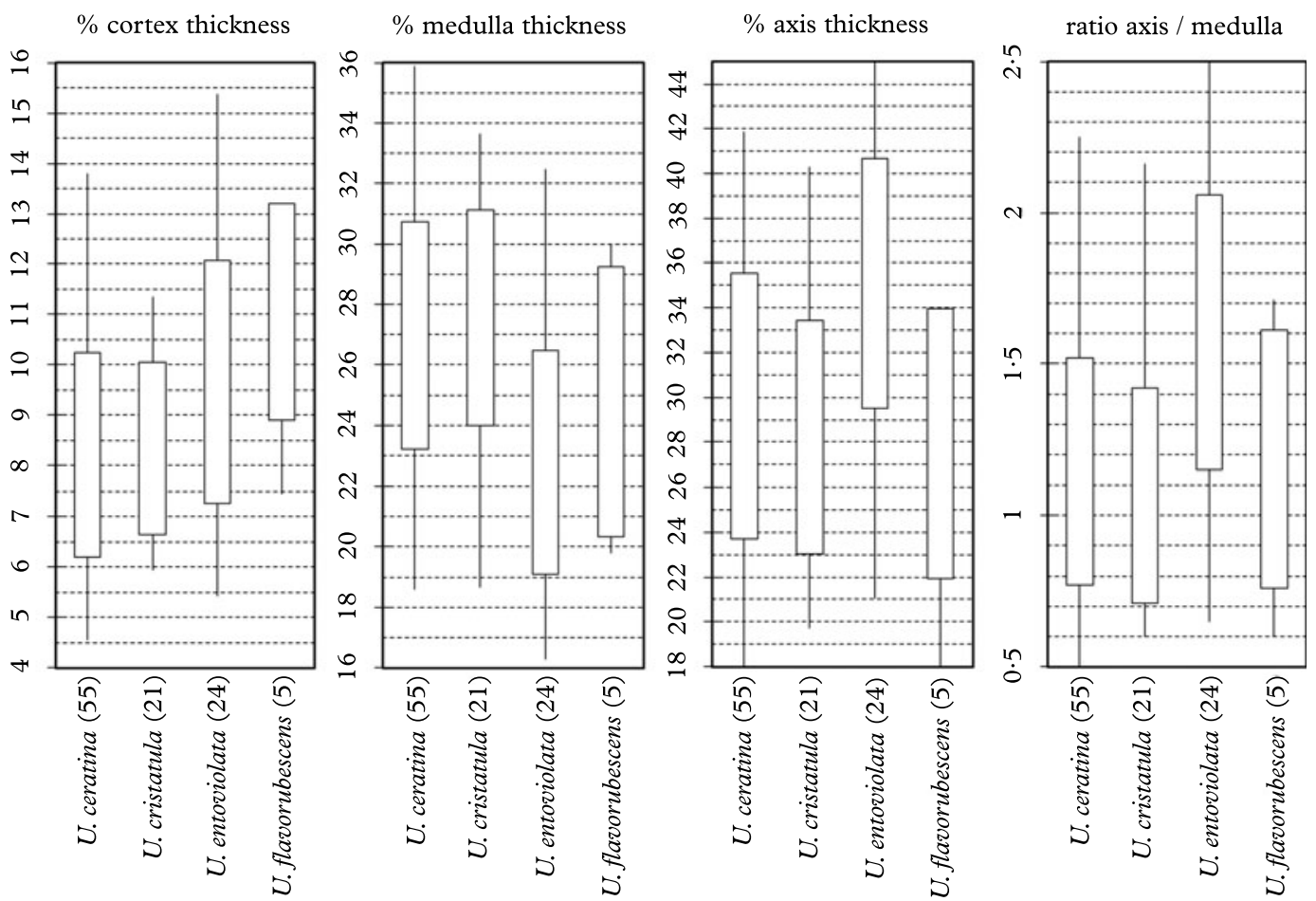

FIG. 1. Percentage of cortex/medulla/axis thickness of total branch diameter (CMA) and ratio of thickness of axis/ medulla in Usnea species. Standard deviations as wide bars; extreme values as lines; number of specimens measured in parentheses.

pink to rose/yellowish medulla, reacting $\mathrm{C}+$ yellow. The soralia remain minute or eventually fuse or enlarge more than the halfbranch diameter, with a \pm irregular outline, often becoming convex at maturity, usually with numerous short isidiomorphs (Fig. 3G). Diffractaic acid or (more rarely) barbatic acid are the major metabolites detected in the medulla by TLC (Table 2 ).

Variation. Usnea ceratina has a variable morphology, especially in the shape of branches (tapering to irregular in diameter, Fig. 3A), the shape of segments in cross section (usually terete but often flattened or ridged, Fig. 3B), the rigidity of the thallus (typically stiff to flaccid) and the abundance of fibrils, papillae, tubercles and soralia. Several thalli may exhibit inflated branches that are slightly constricted at the attachment point (Fig. 3C), similarly to $U$. cornuta Körb. This correlates with a cornuta-type CMA (Truong et al. 2011) and an $\mathrm{A} / \mathrm{M}$ ratio $<1$. This morphotype has been correlated with non-favourable conditions, such as polluted environments (Herrera-Campos et al. 1998; James et al. 2009). We did not observe such a correlation in South America but we also were not able to correlate this morphotype with any other morphological, chemical or ecological characters.

The location and concentration of the medullar pigmentation is highly variable (Fig. 2A-C): the pigmentation is typically redpurple towards the cortex, with various tones present from pink (29-30-36-37 in Isley 1987) to rose (38), rarely purple (39). Towards the axis the medulla is white to pale yellow (1), reacting $\mathrm{C}+$ yellow (2-3). The medulla is rarely exclusively pale yellow (1) or almost white. In such cases the $\mathrm{C}+$ yellow reaction facilitates the identification of this species. 


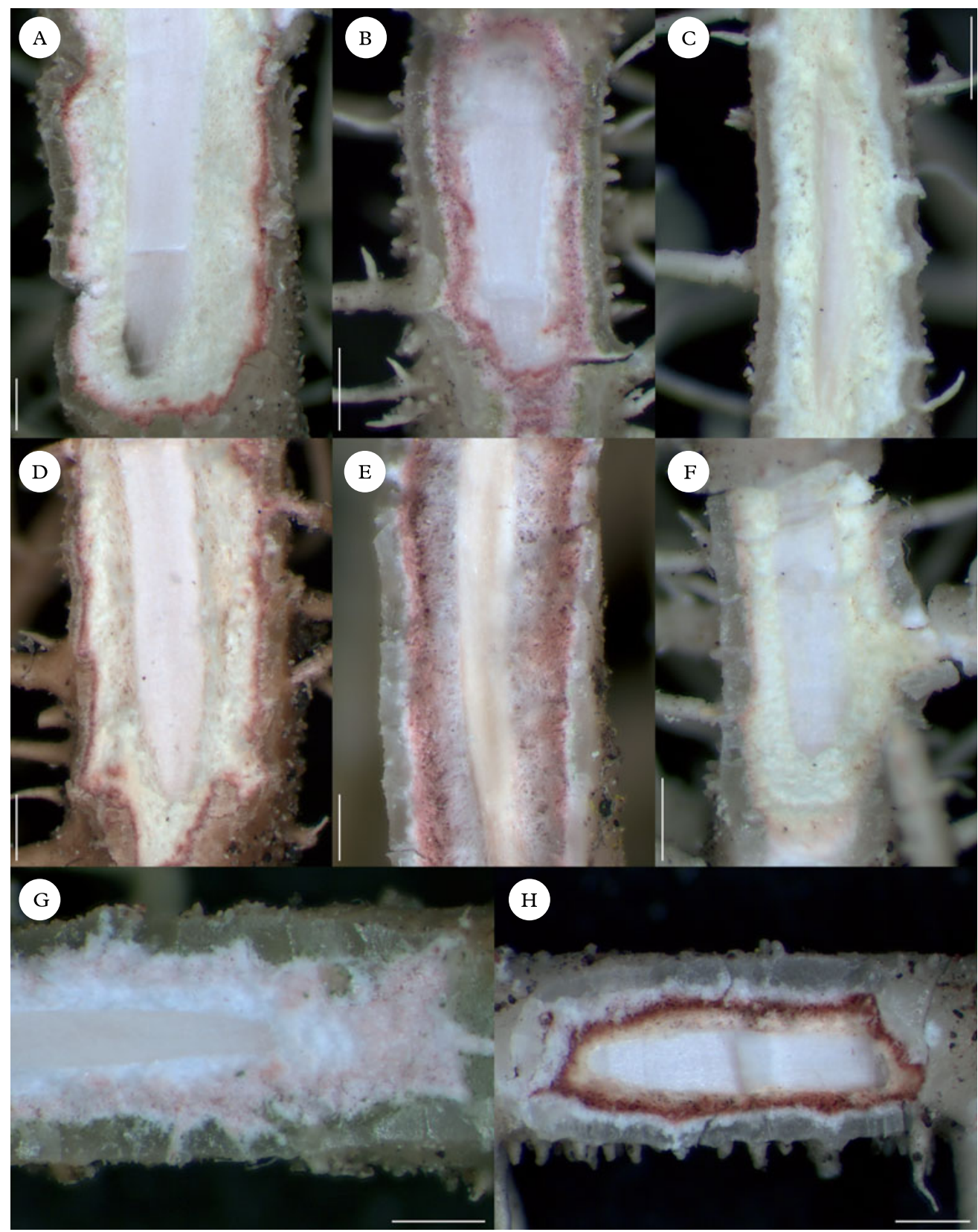

FIG. 2. Variation in the colour and location of the medullary pigmentation in Usnea species. A-C, U. ceratina; A, pigmentation pink to rose towards the cortex and pale yellow towards the axis (Truong 2739); B, pigmentation pink to rose, almost subcortical (Truong 3251); C, pigmentation pale yellow, periaxial (Truong 2443). D-F, Usnea cristatula; D, pigmentation pink to rose, subcortical, very thin (Hale 46870); E, pigmentation pink to rose, almost subcortical, thicker (Truong 683); F, pigmentation pink towards the cortex and pale yellow towards the axis (Truong 1811). G, U. entoviolata, pigmentation usually pink to rose, almost subcortical (Bach 633). H, U. flavorubescens (Truong 624), pigmentation periaxial, forming two layers (golden yellow then red), staying well separated from the cortex by a layer of white medullary tissue. Scales: $\mathrm{A}-\mathrm{H}=500 \mu \mathrm{m}$. 


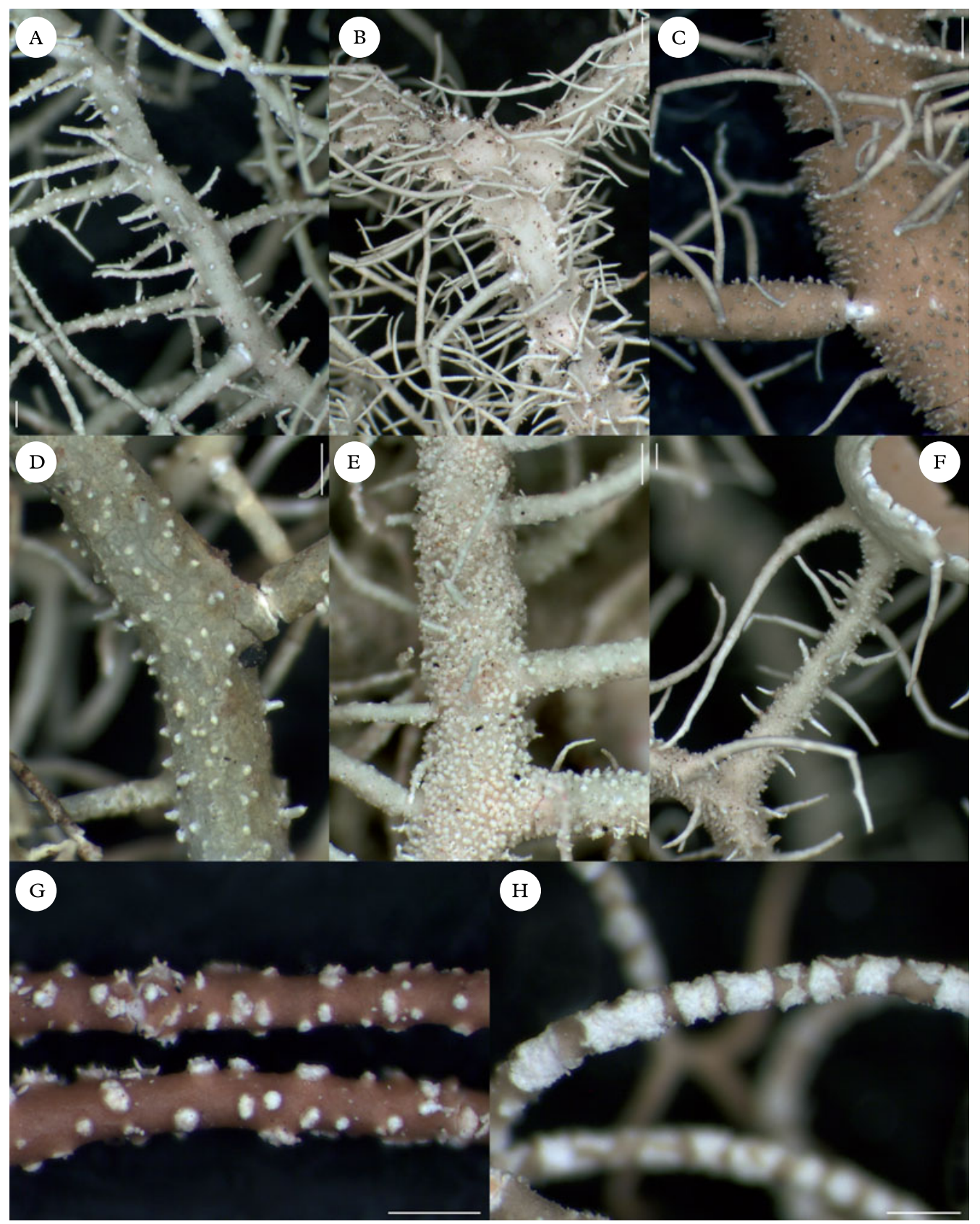

FIG. 3. A-C, U. ceratina, variation in the shape of branches; A, branches irregular in diameter, with slightly flattened segments; branches not constricted at the attachment point (Truong 3251); B, branches with ridged segments (Truong 1840); C, branches constricted at the attachment point (Aguirre E Sipman 6168). D-F tubercles; D, U. ceratina (Truong 3864); E \& F, U. cristatula; E, numerous tubercles densely covering the branches (Truong 2799); F, fibrils and tubercles on branches supporting apothecia (Truong 1724). G \& H, soralia; G, U. ceratina (Hale 46893), minute, distinctly stipitate soralia with numerous isidiomorphs; H, U. entoviolata (Aguirre E Sipman 5640C), large and excavate soralia encircling the branch, without isidiomorphs. Scales: $\mathrm{A}-\mathrm{H}=500 \mu \mathrm{m}$. 
Differentiation. See under U. entoviolata.

Ecology and distribution. This is primarily a corticolous species that grows on a wide variety of trees and shrubs. Occasionally it is also lignicolous (on dead trunks or fences) or saxicolous. In tropical South America, it covers an impressive altitudinal range (600$3500 \mathrm{~m}$ ) and is found in a wide variety of habitats: from Neotropical savanna (cerrado) to high altitude páramo, in primary and secondary forests (evergreen low montane forests, montane cloud forests, Quercus humboldtii forests, plantations) to the upper tree limit and in open places (pastures with forest relicts, deforested zones of matorral). It seems to be more common in the Andes than in Brazil. This species is widely distributed in the temperate and subtropical regions of Europe, North and South America, East Africa, Asia and Oceania (Ohmura 2001; Clerc 2008).

Selected specimens examined. Bolivia: Cochabamba: Cerca de Corani, 3173 m, 2007, Truong 3044 (G). La Paz: Parque Nacional Alto Madidi, Queara, $3005 \mathrm{~m}$, 2007, Truong 2834 (G)._Brazil: Minas Gerais: Serra da Mantiqueira, Fazenda São Mateus, 1800 m, 1980, Kalb (private hb.). Parana: Ambrósios, mun. Tijucas do Sul, 900 m, 1991, Kummrow \& Barbosa 3258 (B). São Paulo: Reserva biologica Mogi-Guaçu, fazenda Campininha, $640 \mathrm{~m}, 2007$, Fungbluth 1722 (SP).Colombia: Antioquia: Medellin, 1500 m, 1930, Archer 661A (US). Boyaca: Near Arcabuco, 2600 m, 1986, Sipman \& Reyes 34449 (B). Cauca: Popayan, c. $15 \mathrm{~km}$ towards Timbío, $1750 \mathrm{~m}, 1986$, Sipman, Velosa et al. 32759 (B). Cundinamarca: Munic. San Francisco, near Quebrada Cueva Grande, 2500 m, 1986, Sipman, Cardozo \& Ballesteros 23577 (B). Huila: Mnpio. La Plata, headwaters of rio La Candelaria, 2300 m, 1984, Aguirre E Sipman 6168 (B). Nariño: Mnpio. Pasto, along main road to Popayan, $2550 \mathrm{~m}, 1986$, Sipman, Velosa et al. 33645 (B). Santander: slopes of Pico Banderas, Paramo de Tama, 2400 m, 1975, Hale 45787a (US).Ecuador: Azuay: Alrededores del Parque Nacional Cajas, cerca del puente de los Dos Chorreras, 3304 m, 2007, Truong 332 (G). Imbabura: Reserva ecologica Cotacachi-Cayapas, laguna Piñan, 2786 m, 2007, Truong 3251 (G). Loja: Ruta nueva hasta Saragura, $2612 \mathrm{~m}$, 2007, Truong 139 (G). Napo: $5.6 \mathrm{~km}$ south of Baeza, on road to Tena, $1300 \mathrm{~m}, 1985$, Churchill $\mathcal{E}$ Sastre De-fesús s. n. (B). Pichincha: Reserva geobotánica Pululahua, base del cráter, 2478 m, 2007, Truong 3372 (G).-Peru: Cajamarca: Parque Nacional Cutervo, cerca de San Andres de Cutervo, 2794 m, 2007, Truong 1656 (G). Cusco: Santuario histórico de Machu Picchu, alrededores de Wiñaywayna, 2728 m, 2007, Truong 694 (G). Huanuco: Bosque de Carpish, ruta hasta Tingo María, $2424 \mathrm{~m}$,
2007, Truong 2739 (G). Funin: La Merced, districto de San Ramon, catarata Tirol 1078 m, 2007, Truong 2673 (G). Pasco: Parque Nacional Yanachaga-Chemillén, camino hasta el refugio El Cedro, $2309 \mathrm{~m}, 2007$, Truong 2443 (G).-Venezuela: Merida: La Carbonera, MeridaLa Azulita road, 2200 m, 1976, Hale 46878 (US). Tachira: slopes of Pico Banberas, paramo de Tama, 2600 m, 1975, Hale E Lopez-Figueiras 45381 (US).

\section{Usnea cristatula Motyka}

Lich. Gen. Usnea Stud. Monogr. Pars Syst. 2: 641 (1938); type: Mexico, Michoacan, Morelia, Cerro Azúl, Brouard (LBL!-holotype; LBL!, S! - isotypes). \% C/M/A: 11/ $17 \cdot 5 / 42 \cdot 5$. Chemistry: usnic, diffractaic and traces of squamatic acids (Herrera-Campos et al. 1998).

Usnea grandisca Motyka, Lich. Gen. Usnea Stud. Monogr. Pars Syst. 2: 307 (1938); type: Peru, Junin, Tarma, Berge östlich von Palea, 2800-3100 m, 1903, Weberbauer (LBL! - lectotype designated here). \% C/M/A: $5 \cdot 5 / 31 \cdot 5 / 26 \cdot 5$. Chemistry: usnic, diffractaic and barbatic acids.

Nomenclatural note. Although Motyka (1938) indicated that the holotype of $U$. grandisca was deposited in $\mathrm{B}$, this specimen appears to be missing. We found two isotypes of this species deposited in LBL and confirmed that they were identical in morphology and chemistry. Therefore, we designated one specimen as the lectotype and the other specimen can be treated as an isolectotype of this species.

\section{(Figs 2D-F, 3E \& F)}

For a detailed description see HerreraCampos et al. (1998) and Clerc (2008).

Diagnostic notes. Usnea cristatula is a nonsorediate species characterized by the presence of numerous apothecia, with hyaline, obovoid spores $(8 \cdot 0-12.5 \times 5.0-8.5 \mu \mathrm{m}$, $n=108)$. When apothecia are absent, pycnidia are usually visible as small globose protuberances on the terminal branches. The cortex is very hard and vitreous (in longitudinal section), moderately thick to thick (Fig. 1). The medulla is dense to compact, with a pink to rose/yellowish pigmentation reacting $\mathrm{C}+$ yellow. Diffractaic acid or (more rarely) barbatic acid are the major metabolites detected in the medulla by TLC (Table 2).

Variation. This is a very polymorphic species: thalli are erect-shrubby to pendulous, very stiff to flaccid; branches are tapering to irregular in diameter, segments are terete, flattened or ridged in cross-section, and the abundance of fibrils, papillae and tubercles 
varies (Fig. 3E \& F), although tubercles are always present and considered a conspicuous character in this species (Herrera-Campos et al. 1998). Several specimens have inflated branches that are constricted at the attachment point, together with an $\mathrm{A} / \mathrm{M}$ ratio $<1$, similar to $U$. cirrosa Motyka.

The medullary pigmentation (Fig. 2D-F) is typically red-purple towards the cortex, with various tones present from pink (2930-36-37 in Isley 1987) to rose (38), rarely purple (39). Towards the axis the medulla is white to pale yellow (1), reacting $\mathrm{C}+$ yellow (2-3). The medulla is rarely exclusively pale yellow (1) or almost white. In such cases the $\mathrm{C}+$ yellow reaction facilitates the identification of this species.

Differentiation. Usnea cristatula is possibly the fertile counterpart of $U$. ceratina (HerreraCampos et al. 1998), sharing the same morphology, chemotypes and similarities in character variation. Indeed, Usnea ceratina was rarely seen with both soralia and apothecia $(n=3)$. Usnea flavorubescens is another fertile species with a pigmented medulla reacting $\mathrm{C}+$ yellow. It differs by the presence of numerous fibercles and few tubercles. The position and colour of the pigment in Usnea flavorubescens is very distinctive: it forms well-delimited yellow (2-3), orangered (25-26-27-28-32) and white layers from the axis to the cortex (Fig. $2 \mathrm{H}$ ). Usnea flavorubescens also has a relatively opaque or 'milky' cortex (not vitreous) and norstictic acid detected in the medulla by TLC (Table 2). Usnea cristatula and U. flavorubescens were occasionally found growing side by side in the same locality.

Ecology and distribution. This is primarily a corticolous species that grows on a variety of trees and shrubs. Occasionally it is also lignicolous (fence posts) or saxicolous. In tropical South America, it has so far been found only in the Andes. It was found at moderate to high altitude $(1600-3000 \mathrm{~m})$ in a wide variety of habitats: in primary and secondary forests (evergreen low montane forests, montane cloud forests, Quercus humboldtii forests) or in open places (pastures with forest relicts, deforested zones of matorral). Usnea cristatula was previously known from Portugal (Clerc 2011a), the USA (Knudsen \& Lendemer 2006), Mexico (Herrera-Campos et al. 1998; Clerc 2008) and Peru (sub U. grandisca, Clerc 2008).

Selected specimens examined. Bolivia: La Paz: $15 \mathrm{~km}$ de Charazani hacia Apolo, 2400 m, 1997, Bach, Kessler, Gonzales, Acebey E Rapp 252 (B).-Colombia: Cundinamarca: Mnpio. Tena, laguna de Pedro Palo, $2000 \mathrm{~m}$, 1984, Aguirre E Sipman 5646 (B). Huila: Mnpio. La Plata, headwaters of rio La Candelaria, 2300 m, 1984, Aguirre E Sipman 6173 (B). Nariño: Munic. Pasto, along main road to Popayan, 2550 m, 1986, Sipman, Velosa et al. 33645 (B).-Peru: Cajamarca: Parque Nacional Cutervo, cerca de La Capilla, sector cerro Pampa, 2300 m, 2007, Truong 1703 (G). Cusco: Santuario histórico de Machu Picchu, alrededores de Wiñaywayna 2704 m, 2007, Truong 683 (G)._Venezuela: Merida: La Carbonera, Merida-La Azulita road, 2200 m, 1976, Hale 46870 (US). Tachira: Via Villa Paez-Betania, valley of Paramo de Tama, 2000 m, 1975, Hale \& LopezFigueiras 45131B (US).

\section{Usnea entoviolata Motyka}

Lich. Gen. Usnea Stud. Monogr. Pars Syst. 2: 560 (1938); type: USA, Hawaii, Bailey (W!- holotype). \% C/M/A: $9 \cdot 5 / 28 \cdot 5 / 24$. Chemistry: usnic, barbatic, diffractaic and traces of squamatic acids (Clerc 2004).

(Figs 2G, 3H)

Thallus subpendulous to pendulous (rarely erect-shrubby), to more than $50 \mathrm{~cm}$ long, usually relatively stiff; ramifications mainly anisotomic-dichotomous; trunk concolorous with the branches or brownish on the first $\mathrm{mm}$; main branches tapering to irregular; segments terete to slightly flattened in crosssection, rarely slightly inflated; lateral branches not constricted at the attachment point; foveoles and maculae absent; papillae absent or few, hemispherical; tubercles absent or few; fibrils 2-3 (5) $\mathrm{mm}$ long, scattered to abundantly distributed on the thallus; soralia developing from the cortex ad initio, circular and slightly stipitate, minute to enlarging to the branch diameter, becoming excavate at maturity and sometimes encircling the terminal branches, with a regular outline while keeping a cortical margin (except when deeply excavate), usually remaining welldelimited even when crowded on the branches, without or with few, short isidiomorphs (Fig. 
$3 \mathrm{H})$; cortex hard and vitreous in section, moderately thick to thick $(7 \cdot 5-12 \cdot 0 \%)$; medulla dense to compact, moderately thick $(19 \cdot 0-26 \cdot 5 \%)$, with a pink $(29,30,36,37$ in Isley 1987) to rose (38) pigmentation towards the cortex, and a white to pale yellow (1) pigmentation towards the axis (Fig. 2G), reacting $\mathrm{C}+$ yellow; axis moderately thin $(29 \cdot 5-40 \cdot 5 \%)$.

Apothecia very rare $(n=1)$, subterminal to terminal.

Pycnidia not seen.

Diagnostic notes. Usnea entoviolata is characterized by a stiff, sub-pendulous to pendulous thallus, with tapering to irregular branches bearing circular soralia, enlarging to the branch diameter and excavate at maturity, without or with few short isidiomorphs. The cortex surface is relatively smooth, with few papillae or tubercles. In longitudinal section, the cortex is very hard and vitreous and the medulla is pigmented pink to rose/white to yellowish, reacting C+ yellow. Diffractaic acid or (more rarely) barbatic acid are the major metabolites detected in the medulla by TLC (Table 2 ).

Variation. The abundance of papillae, tubercles and fibrils is variable, although the majority of specimens tend to have a smooth cortex with few papillae and scattered fibrils. Soralia of all sizes are present on lateral branches: minute to circular, with a distinct cortical margin, later enlarging to the branch diameter and excavating at maturity, sometimes encircling the terminal branches. The medullary pigmentation varies between several tones of pink to rose (see above) and the pale yellow pigment is often invisible, but the $\mathrm{C}+$ yellow reaction of the medulla is distinctive.

Differentiation. Usnea ceratina shares a similar morphology, medullar pigmentation and range of chemotypes with $U$. entoviolata. It differs in the ontogeny and morphology of soralia (Clerc 2004): in U. ceratina soralia grow from the top of tubercles, thus they are distinctly stipitate, and they bear numerous isidiomorphs. Soralia eventually fuse or enlarge almost to the branch diameter, but in that case they are convex, and they remain distinctly stipitate (never becoming excavate) and of irregular outline (not circular). In addition, the cortex surface of $U$. ceratina is usually covered by numerous papillae and tubercles and tends to appear less smooth than in $U$. entoviolata. Usnea ceratina also has a greater variation in the morphology of branches: segments are terete, flattened or ridged and branches are sometimes inflated and constricted at the attachment point. Such a morphotype was never observed in U. entoviolata.

Ecology and distribution. This is primarily a corticolous species that is often also saxicolous. In tropical South America, it was found at a wide altitudinal range $(450-3000 \mathrm{~m})$, in relatively open habitats (pastures with forest relicts, deforested zones of matorral, upper tree limit), usually in humid places within forest or in the vicinity of the forest, but also in drier climates, for example in the interAndean valleys or in the Brazilian cerrado. In contrast to $U$. ceratina, it seems to be more common in Brazil than in the Andes. Usnea entoviolata is known from North America, the Caribbean region, Africa, Hawaii (Clerc 2004) and south-western Europe (P. Clerc, unpublished data). It is reported here from South America for the first time.

Selected specimens examined. Bolivia: La Paz: Parque Nacional Alto Madidi, Queara, 3005 m, 2007, Truong 2843 (G). Santa Cruz: Prov. Florida, refugio Los Volcanes, 1000 m, 1997, Bach, Kessler, Gonzales E Rapp 633 (B).-Brazil: Mato Grosso: Serra dos Coroados, c. $6 \mathrm{~km}$ südwestlich von Buriti, $600 \mathrm{~m}, 1980$, Kalb (private hb.). Minas Gerais: Bei Lagoa Dourada, c. $50 \mathrm{~km}$ nordöstlich von São João del Rei, 1000 m, 1978, Kalb E Plöbst (private hb.). Parana: Ambrósios, mun. Tijucas do Sul, 900 m, 1991, Kummrow E Cordeiro 3282 (B). Rio de Faneiro: Serra da Mantiqueira, Parque National do Itatiaia, $850 \mathrm{~m}, 1978$, Kalb \& Plöbst (private hb.). São Paulo: Reserva biologica de Mogi-Guaçu, fazenda Campininha, $640 \mathrm{~m}, 2007$, Fungbluth 1719 (SP).Colombia: Boyaca: near Arcabuco, c. $1 \mathrm{~km}$ on the road towards Tunja, 2600 m, 1986, Sipman \& Reyes 34445 (B). Cundinamarca: Mnpio. Tena, laguna de Pedro Palo, 2000 m, 1984, Aguirre \& Sipman 5640C (B). Huila: Mnpio. La Plata, vereda La Candelaria, finca Merenberg, 2400 m, 1984, Aguirre E Sipman 5729 (B). Nariño: Munic. Imues, on road Pasto-Tumaco, 1880 m, 1986, Sipman, Velosa et al. 33545 (B).-Peru: Cajamarca: Parque Nacional Cutervo, La Capilla, sector cerro Pampa, 2237 m, 2007, Truong 1708 (G). Cusco: Ruinen von Machu-Picchu, 1960, Mattick 120B (B).-Venezuela: Merida: La Carbonera, sector El Pedregel, $2100 \mathrm{~m}$, 


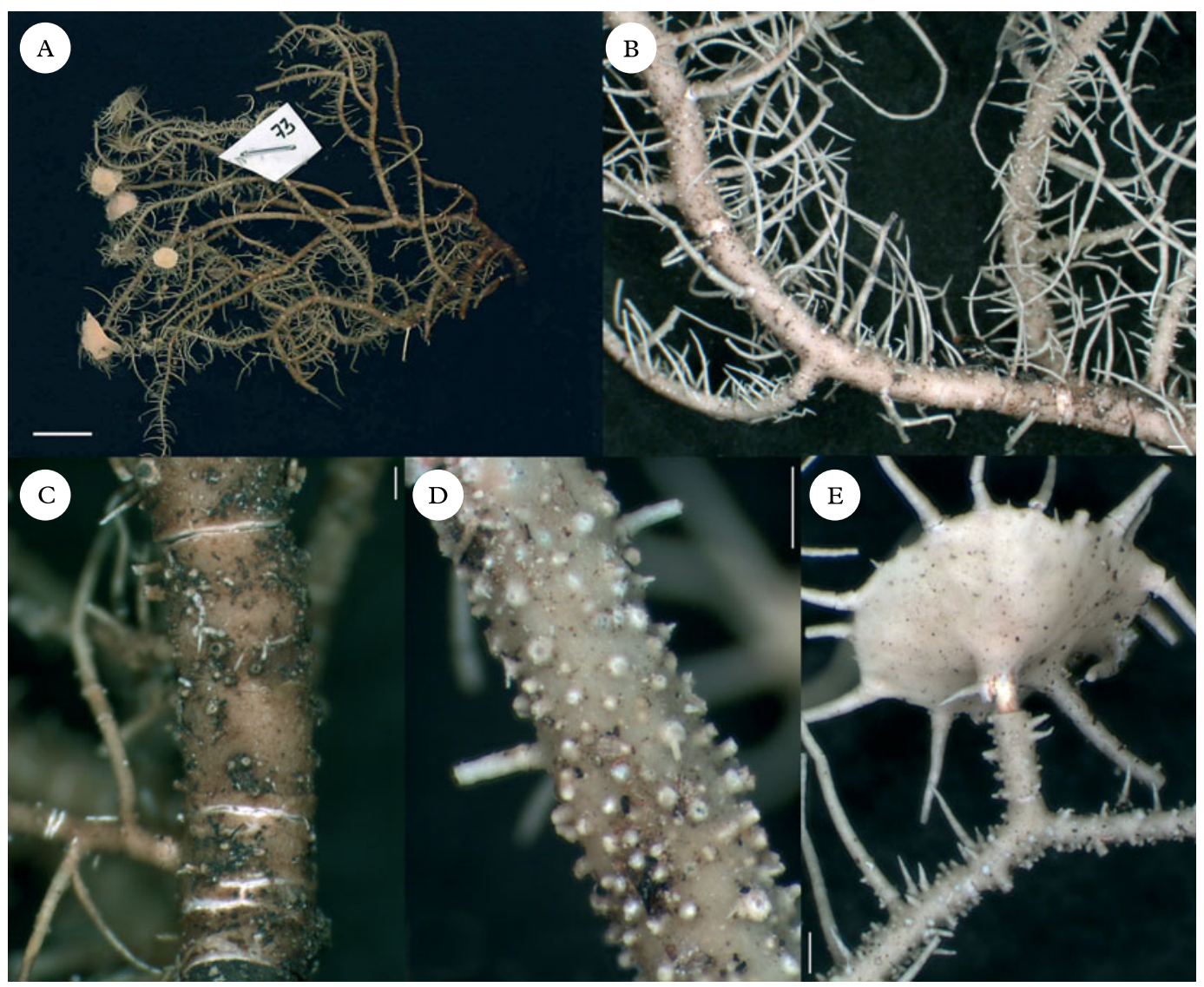

FIG. 4. Usnea flavorubescens; A, holotype; B, branches tapering to irregular in diameter, with slightly flattened segments (Truong 2080); C, base concolorous with few annular cracks (Truong 2080); D, numerous fibercles covering the branches (holotype); E, fibrils and fibercles on branches below apothecia (Truong 624). Scales: $\mathrm{A}=1 \mathrm{~cm}$; $\mathrm{B}-\mathrm{E}=500 \mu \mathrm{m}$.

1975, Hale \& Lopez-Figueiras 44160 (US). Tachira: Via Villa Paez-Betania, valley of paramo de Tama, $2000 \mathrm{~m}$, 1975, Hale E Lopez-Figueiras 45090 (US).

\section{Usnea flavorubescens Truong \& P. Clerc sp. nov.}

MycoBank No: MB 563324

Thallus non-sorediate (usually with apothecia), fibercles abundant, medulla pigmented with yellow periaxial layer, orange to red outer layer and white subcortical layer, norstictic acid in the medulla.

Type: Peru, Cusco, santuario histórico de Machu Picchu, Wiñaywayna, alrededores de la estacion biologica, $2685 \mathrm{~m}$, bosque de neblina montano (secundario), sobre ramas y troncos, 2007, Truong 2067 (USM-holotype;
G-isotype). \% C/M/A: $13 \cdot 5 / 20 / 34$. Chemistry: usnic and norstictic acids, traces of unidentified tri-terpenoids UT18.

(Figs $2 \mathrm{H}, 4 \mathrm{~A}-\mathrm{E}$ )

Thallus erect-shrubby to subpendulous, to $15 \mathrm{~cm}$ long; ramifications mainly anisotomicdichotomous; trunk concolorous with the branches or dark brown on the first $\mathrm{mm}$; branches tapering to irregular. (Fig. 4B), with few annular cracks, mainly visible close to the base of the thallus (Fig. 4C); segments terete to slightly flattened, not inflated; lateral branches not constricted at the attach- 
ment point; foveoles and maculae absent; papillae and tubercles absent or scarce; fibrils $2-3 \mathrm{~mm}$ long (up to $5 \mathrm{~mm}$ ), scattered to abundantly and regularly distributed on the thallus; fibercles conspicuous and often abundant, especially on terminal branches supporting apothecia (Fig 4D-E); soralia absent; cortex hard and shiny, but relatively opaque or 'milky' (not vitreous) in section, moderately thick to thick (9-13\%); medulla dense (but never compact), moderately thin to moderately thick $(20-29 \%)$, with the following pigmentation (Fig. $2 \mathrm{H}$ ): a yellow (2-3 in Isley 1987) periaxial layer reacting C+ yellow-orange (11-12-13), encircled by an orange to red (25-26-27-28-32) outer layer that is well-separated from the cortex by a layer of white medullary tissue; axis moderately thin (22-34\%); apothecia usually present $(n=4)$, subterminal to terminal, with numerous long cilia; spores hyaline, obovoid, 7.0$10.5 \times 5-7 \mu \mathrm{m}(n=30)$.

Pycnidia rare, usually present when apothecia are missing $(n=1)$, appearing as small globose protuberances on terminal branches.

Diagnostic notes. Usnea flavorubescens is a non-sorediate species (usually with apothecia), with a characteristic pigmentation of the medulla, forming a yellow periaxial layer reacting $\mathrm{C}+$ yellow-orange, encircled by an orange to red outer layer that is well-separated from the cortex by a layer of white medullary tissue (Fig. 2H). It has slightly irregular branches (Fig. 4B) with conspicuous, often numerous fibercles (Fig. 4D \& E), a hard and shiny, but relatively opaque (not vitreous) cortex and norstictic acid detected in the medulla by TLC (Table 2).

Differentiation. See under $U$. cristatula for differences with $U$. flavorubescens.

Ecology and distribution. This corticolous or saxicolous species occurs in relatively open places within evergreen low montane forests and montane cloud forests or in deforested zones of matorral. It is so far endemic to Peru, found at two localities in the northern and the south-eastern part of the country (2000-2700 m altitude).

Specimens examined. Peru: Cajamarca: Cerca de Chachapoyas, distrito San Pablo de Valera, catarata Gocta, 1995 m, 2007, Truong 624 (G). Cusco: Santuario histórico de Machu Picchu, Wiñaywayna, subiendo a las ruinas de Intipata, $2689 \mathrm{~m}, 2007$, Truong 3862 (G) and $2704 \mathrm{~m}$, Truong 2080 (G); alrededores de Wiñaywayna, 2704 m, 2007, Truong $684(\mathrm{G})$.

\section{Key to Usnea species with a pigmented, C+ yellow medulla from tropical South America}

1 Axis distinctly tubular throughout the thallus

$\ldots \ldots \ldots \ldots \ldots$ Eumitrioid species (not treated here)

Axis solid, rarely fistulose towards the base $\ldots \ldots \ldots \ldots \ldots \ldots \ldots \ldots$

2(1) Soralia present; apothecia absent or rare; tubercles numerous and fibercles absent or

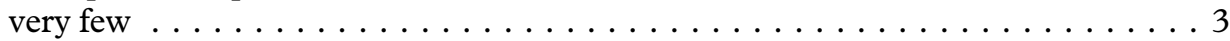

Soralia absent; apothecia usually present, if not, pycnidia typically present as spherical protuberances at the tips of branches; either tubercles or fibercles abundant. . . . 4

3(2) Soralia growing from low tubercles (distinctly stipitate), remaining minute or eventually fusing or enlarging to more than the half-branch diam., with a \pm irregular outline, capitate at maturity (never excavate); isidiomorphs usually numerous . . .

$\ldots \ldots \ldots \ldots \ldots \ldots \ldots \ldots \ldots \ldots \ldots \ldots \ldots \ldots$. ceratina

Soralia growing from the cortex ad initio (slightly stipitate), minute to enlarging to the branch diameter at maturity, circular and remaining well-delimited while keeping a cortical margin (except when deeply excavate), plane to excavate at maturity; isidiomorphs absent or few . . . . . . . . . . . . U. entoviolata 
4(2) Pigmentation forming three well-delimitated layers (yellow, orange-red and white from the axis to the cortex); fibercles numerous; norstictic acid present . . . . . . . $\ldots \ldots \ldots \ldots \ldots \ldots \ldots \ldots \ldots \ldots \ldots \ldots$. flavorubescens

Pigmentation pink to rose (rarely purple) towards the cortex and white to pale yellow towards the axis; fibercles absent or very few, instead with numerous tubercles; norstictic acid absent. . . . . . . . . . . . . . U. cristatula

Fieldwork was supported by the Conservatoire et Jardin Botaniques de la Ville de Genève, a grant 'Augustin Lombard' from the Société de Physique et d'Histoire Naturelle de Genève and a grant from the Amazon Conservation Association. Fieldwork was carried out with the collaboration of the herbaria LPB, QCNE, USM and the Wayqecha Biological Station (Peru). C. Aldana Munguia, M. F. Collaguazo, A. Cuba Villena, Y. Manami, A. Ramirez-Ordaya, P. Rodriguez, L. Salcedo Valdez and A. X. Shuguli assisted in the field. The Ministries of Environment of Ecuador, Peru and Bolivia provided collection permits. The National Parks visited kindly supported our investigation by providing guides and lodging. We thank the curators of the cited herbaria for the loan of specimens. F. Visentin (G) helped with TLC analysis and $M$. Price $(G)$ reviewed the English.

\section{REFERENCES}

Awasthi, G. (1986) Lichen genus Usnea in India. Fournal of the Hattori Botanical Laboratory 61: 333-321.

Clerc, P. (1987a) On the morphology of soralia in the genus Usnea. Bibliotheca Lichenologica 25: 99-102.

Clerc, P. (1987b) Systematics of the Usnea fragilescens aggregate and its distribution in Scandinavia. Nordic Fournal of Botany 7: 479-495.

Clerc, P. (1992) Some new or interesting species of the genus Usnea (lichenised Ascomycetes) in the British Isles. Candollea 47: 513-526.

Clerc, P. (1998) Species concepts in the genus Usnea (lichenized Ascomycetes). Lichenologist 30: 321-340.

Clerc, P. (2004) Notes on the genus Usnea Adanson. II. Bibliotheca Lichenologica 88: 79-90.

Clerc, P. (2006) Synopsis of Usnea (lichenized Ascomycetes) from the Azores with additional information on the species in Macaronesia. Lichenologist 38: 191-212.

Clerc, P. (2008) Usnea. In Lichen Flora of the Greater Sonoran Desert Region Vol. 3 (T. H. Nash, C. Gries \& F. Bungartz, eds): 302-335. Tempe: Lichens Unlimited, Arizona State University.

Clerc, P. (2011a) Notes on the genus Usnea Adans. (lichenized Ascomycota). III. Bibliotheca Lichenologica 106: 41-51.

Clerc, P. (2011b) Usnea. In Nordic Lichen Flora 4 (A. Thell \& R. Moberg, eds): 107-127. Uddevalla: Nordic Lichen Society.

Clerc, P. \& Herrera-Campos, M. A. (1997) Saxicolous species of Usnea subgenus Usnea (lichenized Ascomycetes) in North America. Bryologist 100: 281-301.
Culberson, C. F. \& Ammann, K. (1979) Standardmethode zur Dünnschichtchromatographie von Flechtensubstanzen. Herzogia 5: 1-24.

Culberson, C. F. \& Johnson, A. (1982) Substitution of methyl tert-butyl ether for diethyl ether in the standardized thin-layer chromatographic method for lichen products. Fournal of Chromatography 238: 483-487.

Halonen, P., Clerc, P., Goward, T., Brodo, I. M. \& Wulff, K. (1998) Synopsis of the genus Usnea (lichenized Ascomycetes) in British Columbia, Canada. Bryologist 101: 36-60.

Halonen, P., Myllys, L., Ahti, T. \& Petrova, O. (1999) The lichen genus Usnea in East Fennoscandia. III. The shrubby species. Annales Botanici Fennici 36: 235-256.

Herrera-Campos, M. A., Clerc, P. \& Nash III, T. H. (1998) Pendulous species of Usnea from the temperate forests in Mexico. Bryologist 101: 303-329.

Herrera-Campos, M. A., Nash III, T. H. \& Garcia, A. Z. (2001) Preliminary study of the Usnea fragilescens aggregate in Mexico. Bryologist 104: 235-259.

Isley, P. (1987) Color chart. In Tillandsia: The World's Most Unusual Airplants. Redondo Beach, California: Botanical Press.

James, P. W., Clerc, P. \& Purvis, O. W. (2009) Usnea. In The Lichens of Great Britain and Ireland, 2nd ed. (C. W. Smith, A. Aptroot, B. J. Coppins, A. Fletcher, O. L. Gilbert, P. W. James \& P. A. Wolseley, eds): 918-929. London: British Lichen Society.

Knudsen, K. \& Lendemer, J. C. (2006) Changes and additions to the North American lichen mycota V. Mycotaxon 95: 309-313.

Motyka, J. (1936-38) Lichenum Generis Usnea Studium Monographicum, Pars Systematica (Vol. 1). Leopoldi: privately printed.

Ohmura, Y. (2001) Taxonomic study of the genus Usnea (lichenized Ascomycetes) in Japan and Taiwan. fournal of the Hattori Botanical Laboratory 90: 1-96.

Ohmura, Y., Lin, C. K. \& Wang, P. H. (2010) Three sorediate species of the genus Usnea (Parmeliaceae, Ascomycota) new to Taiwan. Memoirs of the $\mathrm{Na}$ tional Museum of Nature and Science, Tokyo 46: 6976.

Rodriguez, J. M., Estrabou, C., Truong, C. \& Clerc, P. (2011) The saxicolous species of the genus Usnea subgenus Usnea (Parmeliaceae) in Argentina. Bryologist 114: 504-525.

Seymour, F. A., Crittenden, P. D., Wirtz, N., Øvstedal, D. O., Dyer, P. S. \& Lumbsch, H. T. (2007) Phylogenetic and morphological analysis of Antarctic 
lichen-forming Usnea species in the group Neuropogon. Antarctic Science 19: 71-82.

Stevens, G. (1999) A revison of the lichen family Usneaceae in Australia. Bibliotheca Lichenologica 72: 1-128.

Stevens, G. (2004) Usneaceae. In Flora of Australia Vol. 56A, Lichens (P. M. McCarthy \& K. Mallett, eds): 78-98 \& 107-115. Melbourne: ABRS/CSIRO.

Swinscow, T. D. V. \& Krog, H. (1978) Pendulous species of Usnea in East Africa. Norwegian fournal of Botany 25: 221-241.

Swinscow, T. D. V. \& Krog, H. (1979) The fruticose species of Usnea subgenus Usnea in East Africa. Lichenologist 11: 207-252.
Truong, C., Bungartz, F. \& Clerc, P. (2011) The lichen genus Usnea (Parmeliaceae) in the tropical Andes and the Galapagos: species with a red-orange cortical or subcortical pigmentation. Bryologist 114: 477503.

Wirtz, N., Printzen, C. \& Lumbsch, H. T. (2008) The delimitation of Antarctic and bipolar species of neuropogonoid Usnea (Ascomycota, Lecanorales): a cohesion approach of species recognition for the Usnea perpusilla complex. Mycological Research 112: 472-484. 